Research.

\title{
THE INFLUENCE OF EARNINGS MANAGEMENT, AUDIT QUALITY AND CEO DUALITY ON TAX AVOIDANCE
}

\author{
Darwin Marasi Purba \\ STIE Binaniaga, Bogor, Indonesia
}

\begin{abstract}
Received: January 27, 2018; Accepted: April 16, 2018; Published: June 30, 2018 To cite this article: Darwin Marasi Purba, The Influence of Earnings Management, Audit Quality and CEO Duality on Tax Avoidance, The Accounting Journal of BINANIAGA, Vol. 03, No. 01, June 2018, pp. 25 38.
\end{abstract}

Abstract. This study aims to get the empirical evidence about the influence of earnings management, audit quality and CEO duality on the tax avoidance. Tax avoidance has used an effective tax rate (ETR) by calculating the corporate taxes expenses divided by the earnings before income and tax during a certain period.

Population of this research are the manufacturing companies in Indonesia Stock Exchange in 2014-2016 which 48 companies are using the purposive sampling technique. Methods of data analysis has applied the descriptive statistical analysis and multiple linear regression.

These results have indicated that earnings management, audit quality and CEO duality have had a significant effect simultaneously on the tax avoidance. However, partial test results have shown that the audit quality and CEO duality have not affected the tax avoidance. While the earnings manegement has had a significant effect on the tax avoidance.

Keyword: effective tax rate, earnings management, tax avoidance.

\section{INTRODUCTION}

The optimalization of the receiving of taxation sectors in Indonesia which is the fundings resources supporting the economics Indonesia has been encountered a lot of obstacles such as tax avoidance and tax fraud. The main problems of these taxation practices have become more complicated and unique since the application of self assessment in the system of tax collection has been implemented which is in relation with the fourth changes of the Regulation of Income Tax, Regulation No. 36 year of 2008 regarding the fourth change of the Regulation No, 7 year of 1983 regarding the Income Tax and the Issuance of the Regulation No.11 year of 2016 regarding Tax Amnesty which has been eliminating the administration and criminal punishments. Such a freedom given to the tax payers (WP) in order them to calculate, to pay and to report their own tax obligation that has made the tax payer can do their own tax management activities to minimize their taxation payment thru the tax avoidance technique which is not against the law (legal), however, on the other side, tax avoidance is not really wanted by the government (Diantari and Ulupui:2016)

Recently some of tax avoidance and tax fraud cases have occurred in Indonesia, such as, a treasurer individual case at BKD Palembang who had made illegal SSP instead of transfer the tax obligation payment which has caused the losses of the government amounting to Rp 576,971,553.- (Forum Indonesia Taxation, 2016). Another taxation cases which is IKEA case which had been avoiding to pay the taxes for the periode of 2009-2014 amounting to 1 trillion Euros or Rp 14,900 trillion by applying the 
profit sharing technique (Kompas, 16/02/2016). The aforementioned cases are the samples of tax avoidance practices by applying the profit management mechanism. This kind of condition is a dilemma for the stakeholders as the earnings management can be chosen by the management as the company's agents thru the accountancy policies, revenues reporting and economical decision making based on the managemerial consideration refered to the Declaration of Financial Accountancy Standard (PSAK) to recognize the economics issues reflecting to one or more profit measurement (Walker et. al., 2013). This opportunity has made the agents become the opportunist refered to efficient job contract offered to shareholders as the principals to maximize their wealth.

Profit Management Practices has not only been affected by the profit management techniques done by the internal party as the company's agency, but also by the external party which have been an impact to the tax avoidance practice which is an audit quality. According to DeAngelo (1981), Audit quality is classified based on the size of the public accountant office (KAP) either it is included within the Big Four KAP category or not (Christiani and Nugrahanti, 2014). Example, the case of PT Kimia Farma, Tbk in 2001 which had marked up the net profit of 32.6 billion rupiah and was not detectable by the Public Accountant Office (KAP) Hans Tuanakota \& Mustofa. Furthermore the case of PT Telkom, its finance report which had been audited by KAP Eddy Pianto was rejected by the United States Secuirity and Exchange Commission (US SEAC) for the period of 2002 (KPPU 2003 in Setyawan, 2015). The aforementioned of tax avoidances happened in Indonesia has been appointing that the related KAP is not capable to detect any frauds. KAP Big-Four has been certified by the international recommendation which will be doing a very careful audit supervised by the Authority of Finance Service (OJK), Directorate General of Taxation and the company's shareholders accordingly and the result of the audit is reliable.

CEO duality has been an individual problem in any decision making of the company, CEO duality should have to be placed very carefully since it could be the trigger to make the agency problem come up. Applying self assessment system has given an opportunity for the executives as the agent to calculate their own income tax as small as possible. The availability of the CEO is required to make a decision related to the accumulation of company's profit, though, the CEO has not been working optimal to support shareholders either internal or external to maximize their wealth (Obradovic and Gill, 2013). On the other side, the external parties have been monitoring and controlling the obligation tax of the company to reduce any opportunist behavior of the manager defining a certain accountancy policy that could upgrade of downgrade the profit affecting tax avoidance practices.

Profit management and audit quality practices relating to the tax avoidance practice had been performed by some researchers, Syanthi, Sudarma and Saraswati (2012), Damayanti and Susanto (2015), Jayanti (2015), Sari, et.al and Yuwono (2016). Some of the researches have not been yet indicating a consistent result refers to the research of Syanthi, Sudarma and Saraswati (2012) that has not proven yet the profit/earnings management practice which has been doing taxation planning and earnings persistence. The research of Damayanti and Susanto (2015) did not prove the audit quality factor affected tax avoidance. However, the research of Yuwono (2016) had proven the influence of earnings management upon tax avoidance by applying book-tax differences approach. The unconsistent result of the aforementioned research is very crucial and interesting to be studied furthermore since it has still been using the objects of the research before the implementation of the Standard of Finance Reporting based on IFRS (International Financial Reporting Standard) which has been applied since 2013. The difference between this research and the previous one is that this research has applied earnings management and audit quality factors to detect any tax avoidance practice and to increase the CEO duality since the CEO existence is required to make a related decision refers to the earnings accumulation affecting the amount of the tax obligation to be paid. 
This research is necessary to be done to combine the three factors aforementioned which are earnings management, audit quality and CEO duality upon the tax avoidance. The objects of the research are the manufacturing companies registered in the Indonesia Stock Exchange in 2013 - 2016 as they have implemented single taxation tariff of $25 \%$ and the Standard of the Financial Reporting based on IFRS.

\section{LIBRARY REVIEW}

\section{A. The Agency Theory}

The Agency theory is the theory of the connection between the principal and the management party (agent) introduced by Jensen and Mecking in 1976. Scott (2015:340) defined "'Agency theory is a branch of game theory that studies the design of contract to motivate a rational agent to act on behalf of a principal when the agent's interest would otherwise conflict with those of the principal". Conflict of interest has created an agency conflict. This kind of conflict could happen due to the possibility of non-conformity issue between what the agents have been doing with the principal interest. Application of self assessment system could give an opportunity for the management to calculate the earnings tax (PKP) as small as possible. The Standard of the Accountancy stipulated by the Indonesia Accountant Association (IAI) has allowed the management to make a decision applying an accountancy method to send the information of the company's performance to the external party so that the company could reduce the amount of the tax liability. The tendency of the rational managers will choose the accountancy policy which is in accordance with their interest causing an asymmetric information and the agents will use the asymmetric information by doing tax avoidance refers to the taxation management mechanism in order to get their own profit that they cannot get from the contract with the principal.

\section{B. Earnings Management}

Earnings management is the method applied by the manager to influence the amount of the earnings systematically and intentionally by choosing a certain accountancy policy and procedure from the applicable accountancy and scientifically they could maximize their utilities and or the market value of the company (Scott, 2015).

Empiric model had measured the earnings management for the first time done by Healy in 1985 and De Angelo model in 1986, both of them had been calculating the accrued total value (TAC) by reducing the accountancy earnings gained for a certain period along with the operational cash flow at the related period. Then in 1991 Jones model had implemented 2 assumptions as the basic of development, (1) Current accrued period, where any changes in the working capital accounts which is the result of the changes happened in the economical environment of the company connected with the sales change, so that all the variables applied would be divided by the assets and sales of the previous period, and (2) gross property, plant and equipment are one of the main components used for the calculation of accrued total, specially depreciation cost non discretionary (Setyawan, 2015). Earnings distribution approach was developed by Phillips in 2003 to identify the earnings management. This technique has applied earnings threshold and has discovered that the companies under the earnings thresholds will be trying to get thru its limits by doing earnings management. Earnings thresholds are classified into two,: (1) Zero earnings report indicating earnings management efforts to avoid losses reporting; and (2) Zero earnings changes has indicated the efforts of earnings management to avoid profits decrease. (Aditama and Purwaningsih, 2014). 


\section{Audit Quality}

Referring to Arens, Elder and Beasley (2014:26), public accountant office has been classified into 4 categories; (1) The Big Four International Public Accountant Offices; (2) National Public Accountant Offices; (3) Regional Public Accountant Offices and the Big Local Public Accountant Offices; (4) Small local Public Accountant Offices. The quality of the services given by Public Accountant Offices (KAP) could figure out the quality of the service in relation with human resources recruited selectively, the auditors have been chosen based on their competency and skills in the accounting, auditing, taxation and other supported subjects. It explains that the company's financial reporting audited by the Big Four Public Accountant Office is reliable since their auditing service is more independently and transparently disclosing miss-statement provided in the financial reporting refers to the tax avoidance practice.

\section{CEO Duality}

CEO Duality can be defined as both CEO and chairman entitled by only one person. A CEO is competent to motivate and to direct his/her subordinates to do their job properly. In Indonesia the companies who are applying the two-tiers board system having two boards, as follows: (1) managing board or executive board (board of directors); and (2) supervisory board or board of supervisory directors (Board of Commissioners) (Sutedi, 2014:155-156). Referring to Sridharan (1997, in Puspita: 2013), CEO duality could reduce the power of board of directors governing the company and as the main function of the company when they are acting as the shareholders and controlling mechanism within the corporate governance. The company that is having CEO duality is in accordance with the situation when the CEO of the company has had double functions as the chief of board of commissioners.

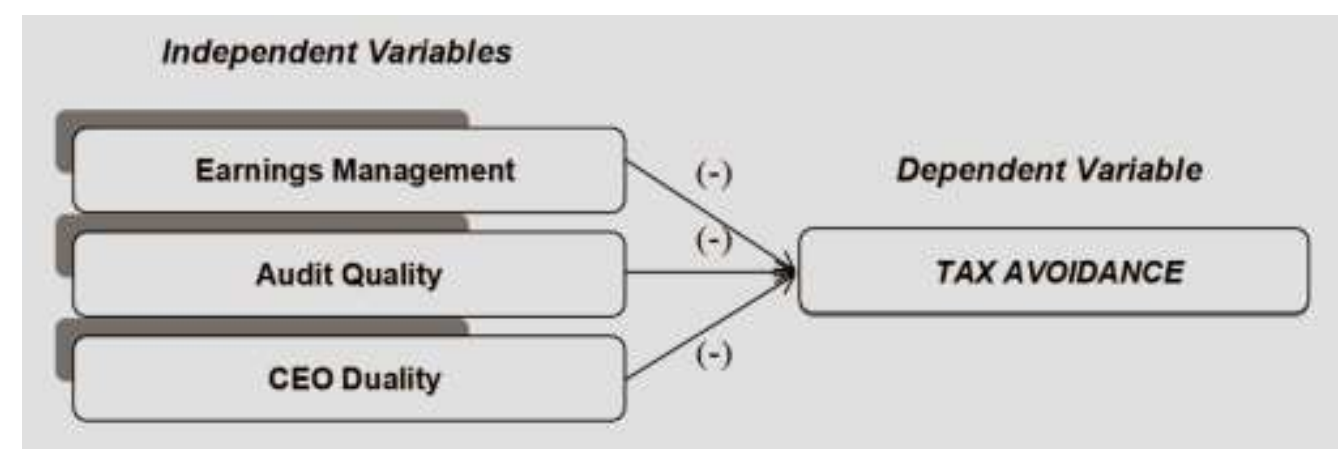

Figure 1 : Research Design

\section{E. Hypothesis}

$\mathrm{H}_{1}$ = Earnings Management has affected significantly tax avoidance.

$\mathrm{H}_{2}=$ Audit Quality has affected significantly tax avoidance

$\mathrm{H}_{3}=$ DEO Duality has affected significantly tax avoidance

\section{RESEARCH METHODOLOGY}

\section{A. Population and Sampling Procedure}

The population of this research are the manufacturing companies listed on BEI (Indonesia Stock Exchange) for the years of 2013-2016. Sampling procedure has applied a purposive method with a certain consideration (Sugiyono, 2015:126), in general it has to be complied with the objective or research issue. The criteria of the

Darwin Marasi Purba: The Influence of Earnings Management, Audit Quality and CEO Duality on Tax Avoidance 
sampling are as follows;

1. The company does not have any subsidiaries.

2. The company has issued yearly report and financial report at the latest on the 31 st of December of the related year.

3. The company has got losses and ETR value of between 0-1.

4. The company has used rupiah currency (IDR) as the currency of reporting that will be converted by using medium exchange rate (KMK).

\section{B. Operational Variables}

\section{Independent variable}

\section{a. Earnings Management}

Earnings Management Variable $\left(X_{1}\right)$ based on the measurement model of Phillips et at. (2003) which has been measured according to the limitation of earnings thresholds. Earnings thresholds has been measured by dividing the differences of company's earnings with the market value of the company equity at the previous year (Aditama and Purwaningsih, 2012)

\section{b. Audit Quality}

Audit Quality Variable $\left(\mathrm{X}_{2}\right)$ of this research has applied dummy variable by classifying the Big Four public accountant identified code ' 1 ' and non Big Four public accountant identified code'O' (De Angelo, in Christiani and Nugrahanti, 2014)

\section{c. CEO Duality}

CEO Duality Variable $\left(X_{3}\right)$ of this research has applied dummy variable by classifying the composition of board of directors who have had double function identified code ' 1 ', and the ones who do not have double function identified code'0' (Abor and Fiador, 2013)

\section{Dependent Variables}

\section{a. Tax Avoidance}

The dependent variable is Tax Avoidance $(Y)$ has applied an effective tax rates (ETR) approach. ETR is a proxy which has been used a lot in the previous research and in order to find out tax avoidance, it could identify its low ETR value (Lanis and Richardson 2013). ETR is measured by dividing the income tax with net profit before tax (EBIT)

\section{b. Method of Analysis}

Method of data analysis has applied multiple regression analysis. And the regression equation model is as follows:

$$
Y=\beta_{0}+\beta_{1} X_{1}+\beta_{2} X_{2}+\beta_{3} X_{3}+\varepsilon
$$

$$
\begin{array}{ll}
\text { Description } \\
\mathrm{Y} & : \text { Tax Avoidance } \\
\mathrm{X}_{1} & : \text { Earnings management } \\
\mathrm{X}_{2} & : \text { Audit Quality } \\
\mathrm{X}_{3} & : \text { CEO Duality } \\
\mathrm{B}_{0} & : \text { Konstansa }
\end{array}
$$

Darwin Marasi Purba: The Influence of Earnings Management, Audit Quality and CEO Duality on Tax Avoidance 


$$
\begin{array}{ll}
\beta_{1}, B_{2}, B_{3} & : \text { Regression Coefficient } \\
\varepsilon & : \text { Error }
\end{array}
$$

\section{RESULT AND DESCRIPTION}

This research has implemented purposive sampling technique refers to sample selection. The population have covered 148 (hundred and forty eight) manufacturing companies registered in the BEI of 2016. The criteria of sample selection has been done by eliminating 101 companies which are having the subsidiaries, one company that does not issue the financial report on 31 December, 22 companies that have been suffering the losses during the investigation period, 4 companies which have been listing or relisting during the period of investigation and 1 company could not be accessed thru www.idx.do.id.

Table 1. Descriptive Statistics of The Research Variables.

Descriptive Statistics

\begin{tabular}{|l|r|r|r|r|r|}
\hline & $\mathrm{N}$ & Minimum & Maximum & Mean & Std. Deviation \\
\hline Earnings management & 48 &,- 0975 & 1,0619 &, 061223 &, 1936084 \\
\hline Audit Quality & 48 & 0 & 1 &, 62 &, 489 \\
\hline CEO Duality & 48 & 0 & 1 &, 29 &, 459 \\
\hline Tax Avoidance & 48 &, 0000 &, 9078 &, 421008 &, 2590401 \\
\hline Valid N (listwise) & 48 & & & & \\
\hline
\end{tabular}

Source: Output SPSS $22.00(2017)$

Tax avoidance variable $(Y)$ has got an average value of 0.421008 at the the minimum and maximum value each of 0.0000 and 0.9078 . Data variation of tax avoidance of 48 samples of manufacturing companies registered in the BEI for the periode of $2014-2016$ relatively big since it is more than $30 \%$ of mean value.

Variable of earnings management $\left(X_{1}\right)$ has identified minimum and maximum value of about -0.0975 up to 1.0619 . It has explained that index or earnings threshold of the manufacturing company has varied obviously. Data variation of tax avoidance of 48 samples of the manufacturing companies registered in the BEl year of 2014 - 2016 has been relatively quite huge since it is more than $100 \%$ over the mean value.

Variable of audit quality $\left(X_{2}\right)$ has indicated the mean value of 0.62 . It means that $62 \%$ of the manufacturing companies audited by the Big Four KAP and the remaining of $38 \%$ of the companies audited by non Big-Four KAP. CEO Duality variable $\left(\mathrm{X}_{3}\right)$ has indicated a mean value of 0.29 . It means that $29 \%$ of manufacturing companies has had the composition of board directors who is having double function and the rest of $71 \%$ is not having a double function. 


\section{A. Test of Classic Assumption}

\section{Normality Test}

Table 2. Result of Kolmogorov-Smirnov Test

\begin{tabular}{|l|c|}
\hline & $\begin{array}{c}\text { The value of Unstandardized } \\
\text { Residual }\end{array}$ \\
\hline Kolmogorov-Smirnov Z & 0,198 \\
\hline Asymp. Sig. (2-tailed) & 0,000 \\
\hline
\end{tabular}

Resources : Result of Data Processing SPSS 22.00 (2017)

The result of Kolmogorov-Smirnov Test on the variable of tax avoidance has identified $p$ value $=0.000$, since $p$ value $<0.05$, so $H_{0}$ is rejected, nevertheless it can be concluded that the data has not distributed normally and it is against the classic assumption. In order to solve the normality problems of this research, Ghozali $(2013,36: 199)$ has provided an alternative data transformation by changing the regression model to semi-log in the natural logarithm to become a new regression equation, as follows;

$$
L n_{-} Y=\beta_{0}+\beta_{1} X_{1}+\beta_{2} X_{2}+\beta_{3} X_{3}+\varepsilon
$$

After having been re-tested the Kolmogorov-Smirnov test (K / S) upon new regression equation, the result of unstandardized residual scatters of LnTAX is as the following figure 2;

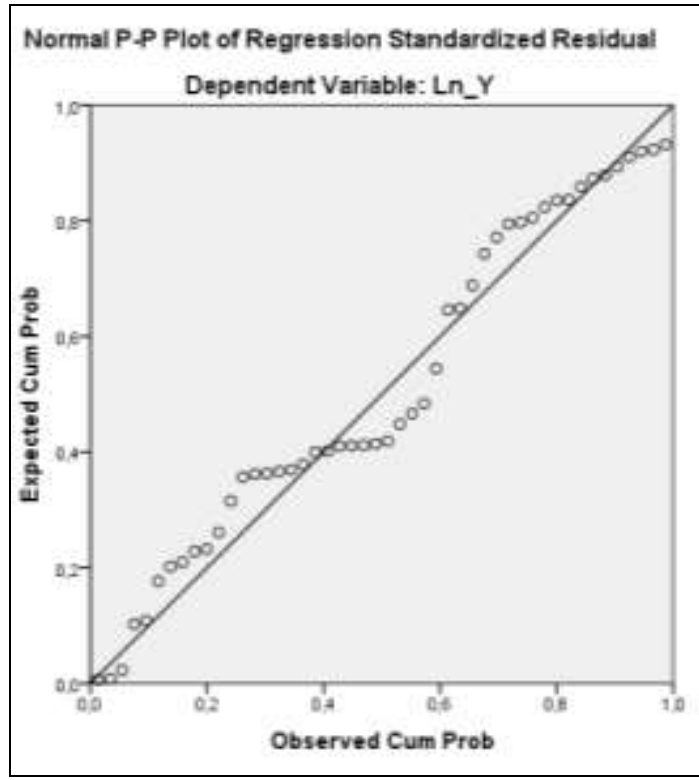

Resource. Output of SPSS 22.00 (2017)

Figure 2. Result of Normality Test of P-Plots Graph 


\section{Heteroscedasticity}

Table 3. Result of Glejser Test

\begin{tabular}{|l|c|}
\hline Research Variables & Sig. value \\
\hline Constant value & 0,000 \\
Earnings management & 0,848 \\
Audit Quality & 0,252 \\
CEO Duality & 0,138 \\
\hline
\end{tabular}

Resource : Result of Data Processing SPSS 22.00 (2017)

Result of heteroscedasticity test is obtained from the regression analysis of coefficient value of independent variables which are earnings management, audit quality and CEO duality upon absolute residual value (AbsUi). This data has explained that all the variables are not significant at the significant levell of 0.05 , furthermore, it could be concluded that this kind of regression model has not indicated any heteroskedasticity problems on the related residual data.

3. Multicolinearity Test

Table 4. Result of Multicolinearity Test

\begin{tabular}{|l|l|l|}
\hline \multicolumn{1}{|c|}{ Independent Variables } & Tolerance & VIF \\
\hline Earnings Management & 0,934 & 1,070 \\
Audit Quality & 0,955 & 1,048 \\
CEO Duality & 0,894 & 1,118 \\
\hline
\end{tabular}

Resource : Result of Data Processing SPSS 22.00 (2017)

The result of multicolinearity test has resulted VIF value of each variable which is less than 10 but tolerance value is more than 0.1 , so that the regression model is free from multicolinierity among the independent variables obviously.

\section{Autocorrelation Test}

Table 5. Result of Autocorrelation Test

\begin{tabular}{|c|c|c|c|c|}
\hline & $\mathrm{d}_{\mathrm{L}}$ & $\mathrm{du}$ & $4-\mathrm{du}$ & $\mathrm{dw}$ \\
\hline Skor & 1,4064 & 1,6708 & 2,3292 & $\mathbf{1 , 9 6 9}$ \\
\hline
\end{tabular}

Resource : Result of Data Processing of SPSS 22.00(2017)

The result of Autocorrelation Test has indicated dw value of 1.969. Value of $d u$ and $d_{L}$ has indicated each of 1.6707 and 1.4064. Autocorrelation test has defined that regression model should have to be between the value of $d u \leq d w \leq$ $(4-\mathrm{du})$. The related value of $d w$ is within the interval of $1.6708<1.969<2.3292$, hence $\mathrm{H}_{0}$ cannot be rejected. Nevertheless, this regression model has not indicated either positive or negative autocorrelation. 


\section{B. Hypothesis Test}

\section{Test of Determinant Coefficient $\left(\mathbf{R}^{2}\right)$}

Table 6. Result of Determinant Coefficient Test

\begin{tabular}{|c|c|c|c|c|}
\hline \multicolumn{5}{|c|}{ Model Summary } \\
\hline Model & $\mathrm{R}$ & R Square & $\begin{array}{l}\text { Adjusted R } \\
\text { Square }\end{array}$ & $\begin{array}{l}\text { Std. Error of } \\
\text { the Estimate }\end{array}$ \\
\hline 1 & $446^{\mathrm{a}}$ & , 199 & 144 & ,64182 \\
\hline
\end{tabular}

a. Predictors: (Constant), Dualitas CEO, Kualitas Audit, Manajemen Laba

b. Dependent Variable: Ln_Y

Resources: Output SPSS 22.00 (2017)

$R$ value of 0.446 has explained that multiple correlations of the independent variables upon the dependent variable is $44.6 \%$. Adjusted $R$ Square $=0.144$ has explained that $14.4 \%$ is the changes of the variable Ln_Y upon tax avoidance that can be described by the variable of earnings management, audit quality and CEO duality, however the rest of $85.6 \%$ has been described by other variables which are not included in this model. The value of standard error of the estimated of 0.64182 is multiple standard error prediction, it explains that the regression model is not very good in predicting tax avoidance since its value is bigger than (>) the deviation standard of dependent variable of 0.2590401 .

2. F-test

Table 7 Result of F-test

\begin{tabular}{|c|c|c|c|c|c|c|}
\hline \multicolumn{7}{|c|}{ ANOVA $^{a}$} \\
\hline \multicolumn{2}{|c|}{ Model } & $\begin{array}{l}\text { Sum of } \\
\text { Squares }\end{array}$ & df & $\begin{array}{l}\text { Mean } \\
\text { Square }\end{array}$ & $\mathrm{F}$ & \\
\hline 1 & Regression & 4,505 & 3 & 1,502 & 3,645 &, $020^{\mathrm{b}}$ \\
\hline & Residual & 18,125 & 44 & ,412 & & \\
\hline & Total & 22,630 & 47 & & & \\
\hline
\end{tabular}

Resource: Output SPSS 22.00 (2017)

Based on the analysis of F-test or ANOVA, p-value is 0.020 and its sig.value is less than alpha $5 \%$, it means that there is a significant effect of the variables of earnings management, audit quality and CEO duality upon tax avoidance.

3. t-test

Table 8 . Result of t-test

\section{Coefficients $^{a}$}

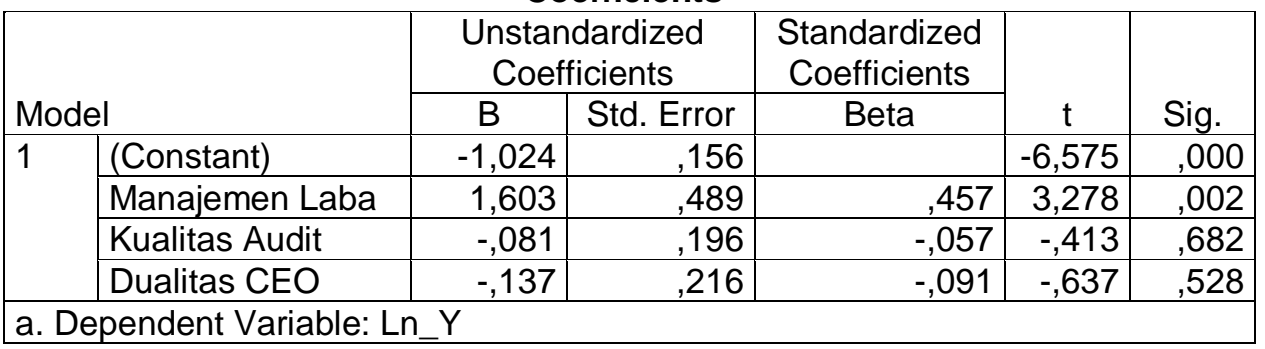

Source: Output SPSS 22.00 (2017)

Darwin Marasi Purba: The Influence of Earnings Management, Audit Quality and CEO Duality on Tax Avoidance 
Based on SPSS 20.00 output, the following regression equation is designed as follows;

$$
\operatorname{Ln} Y \mathrm{Y}=-1,024+1,603 \mathrm{X}_{1}-0,081 \mathrm{X}_{2}-0,137 \mathrm{X}_{3}+\mathrm{è}
$$

Referred to the regression equation result above, it explains that the variable of tax avoidance $(\mathrm{Y})$ within semi-log format has been affected by the independent variables (earnings management, audit quality and CEO duality) and the descriptions are as follows:

Constant

$=-1.024$. It means that earnings management, audit quality and CEO duality are considered constant, hence, tax avoidance is 1.024 unit.

Earnings Management $\left(X_{1}\right)$ has got $\beta$ coefficient of 1.603. It means that if other independent variables value is constant, but earnings management variable has been increasing, nevertheless tax avoidance will be increasing to 1.603.

Audit Quality $\left(\mathrm{X}_{2}\right)$

is having $\beta$ coefficient of 0.081 . It means that if the other independent variables value is constant but audit quality variable has been increasing, however, tax avoidance will be decreasing 0.081 .

CEO Duality $\left(\mathrm{X}_{3}\right)$ is having $\beta$ coefficient of 0.137 . It means that if other independent variables are constant but CEO duality variable has been increasing or developing, nevertheless tax avoidance will be decreasing 0.137 .

\section{The Description of The Research Result.}

Based on the result of t-test hypothesis on the table 8 , the description of the research results related to either the theory or result of the previous research, are as follows:

1. Hypothesis 1 has defined that earnings management has significantly affected tax avoidance. Based on the calculation of multiple linear regression analysis, it has gained regression coefficient value of 1.603 and its probability of 0.002 . The result of this test has indicated that earnings management has affected significantly tax avoidance. The result of this research has been supporting the agency theory which is the tendency of rational managers who will apply the accountancy policy by approaching the earnings management using asymmetric information to perform tax avoidance in the mechanism of taxation management. This research has been in compliance with the research of Syanti and Sudarma (2012), Sari et.al(2016) indicating that earnings management has affected significantly tax planning and tax aggressiveness supporting the investors to execute the analysis of the financial reporting and to understand about the earnings management practicing done by the company. Earnings management is the method that has been done systematically to define a specific accountancy policy and procedure applied on 48 samples of the manufacturing companies within the years of $2014-2016$ using a low effective tax rate which is only $42.1 \%$. Nevertheless, the higher the value of earnings distribution to identify earnings management practicing, the higher the tax avoidance of company will be happened.

2. Hypothesis 2 has determined that audit quality has significantly affected tax avoidance. Based on the calculation of multiple linear regression analysis, it has gained regression coefficient value of -0.081 and the probability of 0.682 . This

Darwin Marasi Purba: The Influence of Earnings Management, Audit Quality and CEO Duality on Tax Avoidance 
result has been in compliance with the research done by Damayanti and Susanto(2015) that did not prove any effect of audit quality happened upon tax avoidance. An auditor is obliged to be independent, competent and professional consideration to evaluate an effective tax rate to identify tax avoidance practicing, if the quality of an audit provided by Public Accountant Office is not reliable, the public trustworthy will be decreasing absolutely and the related KAP will obviously be more carefully evaluating an effective tax rate because it will be controlled periodically by the regulatory especially by the Authority of Finance Service. Nevertheless, this research is not in compliance with the research done by Eksandy (2017) who has proved that audit quality has affected upon tax avoidance. Nevertheless, audit quality which is either from Big-4 KAP and non Big-4 KAP is not in the position of evaluating tax avoidance practices.

3. Hypothesis 3 has determined that CEO Duality has significantly affected tax avoidance. Based on the calculation of multiple linear regression analysis, it has gained the value of regression coefficient of -0.137 and the probability of 0.528 . This result has supported the research done by Mansourina et al.(2013) which did not prove the effect of CEO Duality upon the policy of company's dividend had happened. CEO Duality is the center of power which affecting some of the company's policy, including the activity of tax planning which is indirectly has been determining the amount of effective tax rate (ETR). Therefore, CEO Duality which owned by the company has not fully evaluated the company's policy as well as tax avoidance practicing.

\section{CONCLUSION AND SUGGESTIONS}

\section{A. Conclusion} follows;

Based on the result and description of the research, it can be concluded as

1. Earnings management has been significantly affected tax avoidance.

2. Audit Quality has not significantly affected tax avoidance.

3. CEO Duality has not significantly affected tax avoidance.

\section{B. Suggestions}

1. For the purpose of regulatories and Financial Service Institutions, this research can be an important input to identify earnings management practice that was applied by the related companies refers to the activities of tax management at the companies registered in $\mathrm{BEI}$.

2. For the purpose of the taxation services, this research is expected to be an important input to review the effective tax rate of the company, especially for the companies which are having a very low ETR.

3. For the purpose of the companies, this research has provided an important input to be able to choose a chain of accountancy policies and procedures to measure the earnings management using a specific approach.

4. For the purpose of next researcher, this research is expected to be able to give a contribution in the theoretical development, specifically in the taxation issue regarding the effect of earnings management, audit quality and CEO duality upon tax avoidance, nevertheless it could be used as a reference for the future research.

Darwin Marasi Purba: The Influence of Earnings Management, Audit Quality and CEO Duality on Tax Avoidance 


\section{REFERENCES}

Abor, Joshua, and Fiador, V. (2013). Does corporate governance explain dividend policy in Sub-Saharan Africa?. International Journal of Law and Management. 55 (3), 201-225.

Aditama, F. dan Purwaningsih, A. (2014). Pengaruh perencanaan pajak terhadap manajemen laba pada perusahaan non manufaktur yang terdaftar di Bursa Efek Indonesia. MODUS. 26 (1), 33-50.

Arens, Alvin A., Elder, Randal J., Mark S. Beasley. (2014). Auditing and assurance service, an integrated approach. (Global Edition). England: Pearson Education Limited.

Christiani, I. dan Nugrahanti, Y. W. (2014). Pengaruh kualitas audit terhadap manajemen laba. Jurnal Akuntansi dan Keuangan. 16 (1), 52-62.

Damayanti, F. dan Susanto, T. (2015). Pengaruh komite audit, kualitas audit, kepemilikan institusional, risiko perusahaan dan return on assets terhadap tax avoidance. ESENSI Jurnal Bisnis dan Manajemen. 5 (2), 187-206.

Diantari, P. R. dan Ulupui, IGK Agung. (2016) Pengaruh komite audit, proporsi komisaris independen, dan proporsi kepemilikan institusional terhadap tax avoidance. EJurnal Akuntansi. 16 (1), 702-732.

Eksandy, A. (2017). Pengaruh komisaris independen, komite audit, dan kualitas audit terhadap penghindaran pajak (tax avoidance) (studi empiris pada sektor industri barang konsumsi yang terdaftar di Bursa Efek Indonesia periode 2010-2014). Competitive. 1 (1), 1-20.

Forum Pajak Indonesia. (2016). Penggelapan pajak, bendahara bkd palembang dipenjara 2 tahun 3 bulan. Diakses 04 Desember 2017 $<$ http://forumpajak.org/penggelapan-pajak-bendahara-bkd-palembangdipenjara-2-tahun-3-bulan/>

Ghozali, Imam. 2013. Aplikasi analisis multivariate dengan program: IBM SPSS 21 update PLS regresi. Edisi Ke-7. Semarang: Badan Penerbit Universitas Diponogoro. (Application of Multivariated Analysis using the program of IBM SPSS 21 Update PLS Regression.)

Harian Kompas. (2016). Ikea dituduh hindari pajak hingga Rp 14.900 triliun. Diunduh 26 Agustus 2017. <http://properti.kompas.com/read/2016/02/16/081748621/ Ikea.Dituduh.Hindari.Pajak. hingga.Rp.14.900.Triliun>

Jayanti, P. D. (2015). Pengaruh manajemen laba dan corporate social responsibility terhadap tax avoidance (studi pada perusahaan pertambangan dan pertanian yang terdaftar di Bursa Efek Indonesia tahun 2011-2014). Skripsi Universitas Airlangga: Surabaya.

Mansourinia, E., M. Emamgholipour, E. A. Rekabdarkolaei, dan M. Hozoori. (2013). The effect of board size, board independence and ceo duality on dividend policy of companies: evidence from tehran stock exchange. International Journal of Economy, Management and Social Sciences. 2 (6), 237-241.

Obradovich, D. J. dan Gill, S. (2013). Corporate governance, institutional ownership, and the decision to pay the amount of dividends: Evidence from USA. International Research Journal of Finance and Economics. 97, 60-71.

Darwin Marasi Purba: The Influence of Earnings Management, Audit Quality and CEO Duality on Tax Avoidance 
Puspita, H. O. K. (2013). Pengaruh CEO duality dan interlocking directorship terhadap smoothness laba (studi empiris pada perusahaan manufaktur di Bursa Efek Indonesia). Diunduh tanggal 28 Agustus 2017. <http://eprints.perbanas.ac.id/1246/1/ARTIKEL\%20ILMIAH.pdf>

Richardson, G., Taylor, G., dan Lanis, R. (2013). The Impact of board of director oversight characteristics on corporate tax aggressiveness: an empirical analysis. Journal Accounting and Public Policy. 32, 68-88.

Sari, Winda N., Pratomo, D. dan Yudowati, S. P. (2016). Pengaruh manajemen laba terhadap agresivitas pajak. E-Proceeding of Management. 3 (2), 1530-1535.

Scott, W. R. (2015). Financial accounting theory $\left(7^{\text {th }}\right.$ ed). New Jersey: Prentice-Hall International, Inc.

Setyawan, B. (2015). Pengaruh beban pajak tangguhan, profitabilitas dan perencanaan pajak terhadap manajemen laba (studi empiris pada perusahaan manufaktur sub sektor otomotif dan komponen yang terdaftar di Bursa Efek Indonesia) periode 2010-2014. Tesis Program Pasca Sarjana Universitas Mercu Buana: Jakarta

Sugiyono. (2015). Metode penelitian kombinasi (mixed methods). Cetakan ke-5, Bandung: CV. Alfabeta. (Research Mixed Method)

Sutedi, A. (2014). Hukum ekspor impor, Cetakan ke-1. Jakarta: Raih Asa Sukses.

Syanthi, Nila T., Sudarma, M. dan Saraswati, E. (2012). Dampak manajemen laba terhadap perencanaan pajak dan persistensi laba. ekuitas: Jurnal Ekonomi dan Keuangan Akreditasi No. 80/DIKTI/Kep/2012. 17 (2), 192-210.

Undang-Undang Republik Indonesia Nomor 36 Tahun 2008 tentang Pajak Penghasilan. (Acts of the Republic of Indonesia No.36 year of 2008 regarding Income Tax.

Walker, M. (2013). How far can we trust earnings numbers? What research tells us about earnings management. Accounting \& Business Research. 43 (4), 445-481.

Yuwono, Andrie. (2016). Pengaruh manajemen laba terhadap tax avoidance. Skripsi Widya Mandala Catholic University: Surabaya.

Darwin Marasi Purba: The Influence of Earnings Management, Audit Quality and CEO Duality on Tax Avoidance 
The Accounting Journal of BINANIAGA Vol. 03, No. 01, June 2018

PISSN: $2527-4309$

EISSN: 2580 - 1481

This page intentionally be emptied.

Darwin Marasi Purba: The Influence of Earnings Management, Audit Quality and CEO Duality on Tax Avoidance

Page : 38 